\title{
PENGARUH KONSENTRASI SUBSTRAT PADA PEMBUATAN MALTODEKSTRIN DARI SUBSTRAT PATI SAGU
}

\author{
(Effect Of Substrate Concentration Variation In Maltodextrin Production From Sago \\ Starch)
}

\author{
Amran Laga ${ }^{1 *}$, Andi Dirpan ${ }^{1)}$, dan Aisyah Amini Anshari ${ }^{1)}$ \\ ${ }^{1 *}$ Program Studi Ilmu dan Teknologi Pangan Departemen Teknologi Pertanian Universitas Hasanuddin \\ Makassar, Indonesia \\ *)email Penulis Korespondensi: amranlaga@yahoo.co.id
}

\begin{abstract}
ABSTRAK
Tujuan dari penelitian ini adalah untuk melihat pengaruh konsentrasi substrat pati sagu yang optimal untuk menghasilkan maltodekstrin. Penelitian ini terdiri dua faktor. Faktor A (penggunaan konsentrasi) terdiri dari 4 taraf sagu 20\%, 25\%, 30\% dan 35\% dan faktor B (lama reaksi likuifikasi) terdiri dari 7 taraf yaitu 0 menit, 20 menit, 40 menit, 60 menit, 80 menit, 100 menit, 120 menit. Parameter yang diamati adalah nilai gula pereduksi, total padatan, nilai dekstrosa ekuivalen, kadar pati sisa dan viskositas. Data yang didapatkan diolah dengan menggunakan Rancangan Acak Lengkap (RAL) jika perlakuan memberi hasil signifikan dilanjutkan dengan uji lanjut Duncan. Analisa sidik ragam menunjukkan konsentrasi terbaik dalam hidrolisis maltodekstrin adalah penggunaan konsentrasi $35 \%$ dari segi parameter gula pereduksi, total padatan, dekstrosa ekuivalen dan viskositas dengan nilai sebesar $138.69 \mathrm{~g} / \mathrm{L}, 39.41 \%$, 35.37\% dan $5021.43 \mathrm{cP}$. Lama hidrolisis terbaik dalam pembentukan maltodekstrin adalah pada 120 menit dari segi parameter gula pereduksi, total padatan dekstrosa ekuivalen dan viskositas dengan nilai sebesar $158.25 \mathrm{~g} / \mathrm{L}, 41.28 \%$, $38.35 \%$ dan $1701.42 \mathrm{cP}$
\end{abstract}

Kata Kunci : maltodekstrin, sagu, konsentrasi substrat, hidrolisis enzim

\begin{abstract}
The aims of this research were to examine the effect of the optimal sago substrate concentration to produce maltodextrin. This research consists of two factors. First factor was sago concentration that consists of 4 levels $(20 \%, 25 \%, 30 \%$ and $35 \%)$ and the second was time of liquefaction that consisting of 7 levels $(0$ minutes, 20 minutes, 40 minutes, 60 minutes, 80 minutes, 100 minutes, and 120 minutes). Parameters of observation were reducing sugar levels, total solid, the values equivalent dextrose, residual starch and viscosity. Data were analyzed using a completely randomized design if treatment had real effect on parameter then continued with Duncan test. The result of the research was the best concentration in maltodextrin hydrolysis was in concentration of $35 \%$ in terms of reducing sugar levels, total solids, equivalent dextrose and viscosity with each value $138.69 \mathrm{~g} / \mathrm{L}, 39.41 \%, 35.37 \%$ and $5021.43 \mathrm{cP}$. While the he best reaction time liquefaction of maltodextrin at 120 minutes with reducing sugar levels, total solid, the values dextrose equivalent and viscosity with each value of $158.25 \mathrm{~g} / \mathrm{L}, 41.28 \%, 38.35 \%$ and $1701.42 \mathrm{Cp}$.
\end{abstract}

Keywords : Maltodextrin, sago, substrate concentration, enzyme hydrolysis

\section{PENDAHULUAN}

Produksi sagu yang dikelola dengan baik dapat mencapai 25 ton pati kering/ ha/tahun (Perkebunan, 2008). Sedangkan pemanfaatan sagu saat ini masih sebatas pemanfaatan primer berupa tepung sagu. Tepung sagu juga dapat menunjang 
berbagai macam industri, baik industri kecil, menengah, maupun industri berteknologi tinggi. Misalnya, pemanfaatan tepung sagu sebagai bahan utama pembuatan makanan seperti roti, mie, industri kerupuk, serta kue kering maupun bahan tambahan untuk industri pangan. Padahal, dengan modifikasi tepung sagu menjadi maltodekstrin dapat memberikan lebih banyak manfaat dalam industri pangan, bahkan farmasi antara lain pada pemanfaatan maltodekstrin produksi makanan beku, rerotian, bahan minuman prebiotik, hingga bahan penyalut lapis tipis (film coating) tablet.

Maltodekstrin merupakan produk hidrolisis pati yang mengandung unit $\alpha$-Dglukosa yang sebagian besar terikat melalui ikatan 1,4 glikosidik dengan Dextrose Equivalent kurang dari 20. Hidrolisis pati menjadi maltodekstrin dapat dilakukan dengan berbagai cara diantaranya adalah dengan menggunakan asam dan enzim. Metode hidrolisis menggunakan asam memiliki kelemahan diantaranya tidak ramah lingkungan, karena residu yang dihasilkan dari proses hidrolisis asam akan mencemari lingkungan. Oleh karena itu, modifikasi pati secara hidrolisis menggunakan enzim lebih baik, karena memiliki keunggulan dibandingkan dengan hidrolisis menggunakan asam. Proses hidrolisis pati secara enzimatik juga lebih ekonomis, dapat dilakukan pada suhu rendah dan mudah dalam pengontrolan proses hidrolisisnya (Sadegh, Shahidi, \& Mortazav, 2008). Proses hidrolisis pati dengan enzimatis dilakukan melalui tiga tahapan yaitu tahap gelatinisasi, likuifikasi dan sakarifikasi (Patent 6,054,302, 2000). Secara umum, pembuatan maltodekstrin berlangsung pada proses liquifikasi.

Salah satu faktor yang mempengaruhi reaksi katalitik enzim produk maltodekstrin adalah besar konsentrasi substrat yang akan digunakan. Menurut (Vasanthan \& Bhatty, 1996) substrat dengan konsentrasi rendah menyebabkan enzim tidak semuanya berikatan dengan substrat, sehingga kecepatan maksimum tidak dapat tercapai.
Sebaliknya pada substrat konsentrasi tinggi, semua molekul enzim dapat membentuk ikatan kompleks dengan substrat, sehingga kecepatan reaksi katalitik menjadi lebih lama. Oleh karena itu, penggunaan konsentrasi substrat terbaik perlu diketahui untuk produksi maltodekstrin yang lebih efisien.

\section{METODOLOGI PENELITIAN}

\subsection{Alat}

Alat-alat utama yang digunakan dalam pelaksanaan penelitian adalah ketel likuifikasi, spektrofotometer, gelas kimia, labu ukur, erlenmeyer, cawan petri, pingset, pipet volum, pipet mikro, bulp, sendok, blower, penangas, cawan aluminium, tabung reaksi, oven, dan timbangan analitik.

\subsection{Bahan}

Bahan-bahan utama yang digunakan dalam pelaksanaan penelitian meliputi tepung sagu jenis Metroxylon yang didapat dari daerah Luwu, Sulawesi Selatan. enzim $\alpha$-amilase dari Aspergillus oryzae, enzim pullulanase, $\mathrm{HCl}, \mathrm{NaOH}, \mathrm{CaCl} 2, \mathrm{DNS}$, aquades, alumunium foil, tissue, dan kertas label.

\subsection{Prosedur Penelitian}

Suspensi sagu dibuat dengan konsentrasi 20\%, 25\%, 30\% dan 35\%, ditambahkan Ion kalsium dalam bentuk $\mathrm{CaCl}_{2}$ sebanyak $50 \mathrm{ppm}$. $\mathrm{pH}$ suspensi diatur dengan menambahkan $\mathrm{HCl}$ atau $\mathrm{NaOH}$ hingga $\mathrm{pH} 6.5$ dan ditambahkan enzim $\alpha$ Amilase $0.1 \%$. Suspensi tepung sagu digelatinisasi dengan suhu $105{ }^{\circ} \mathrm{C}$ selama 5 menit. Enzim $\alpha$-Amilase $0.1 \%$ dan pullulanase $0.03 \%$ ditambahkan dalam suspensi. Suhu suspensi pati sagu diturunkan sampai suhu $60^{\circ} \mathrm{C}$ selama 5 menit. Suhu likuifikasi suspensi kembali dinaikkan hingga $80^{\circ} \mathrm{C}$ dan disampling setiap 20 menit selama 120 menit.

\subsection{Desain Penelitian}

Penelitian ini kombinasi perlakuan. Penelitian tahap kedua terdiri atas faktor A 
(konsentrasi substrat) dengan 4 jenis perlakuan dan B (lama reaksi likuifikasi) dengan 4 jenis perlakuan, sehingga diperoleh 16 kombinasi perlakuan. Setiap perlakuan diulang sebanyak dua kali pengulangan sehingga diperoleh 32 satuan percobaan. Pengolahan data dilakukan dengan metode Rancangan Acak Lengkap (RAL) dengan 2 kali ulangan. Apabila hasilnya berbeda nyata maka akan dilakukan uji beda jarak nyata Duncan (BJND) sebagai uji lanjutan.

\subsection{Parameter Pengamatan}

Parameter pengamatan pengujian yaitu Penentuan Kadar Gula Pereduksi metode DNS (Miller, 1959) Penentuan Kadar Air metode Oven dan Total Padatan, Penentuan DE (Dekstrosa Ekuivalen), Penentuan kadar sisa pati metode Iod (Laga, 2001), dan Pengujian Viskositas.

\section{HASIL DAN PEMBAHASAN}

\subsection{Gula Pereduksi}

Gula pereduksi merupakan gula yang mempunyai kemampuan untuk mereduksi suatu senyawa-senyawa penerima elektron, hal ini dikarenakan adanya gugus aldehid dan keton bebas.

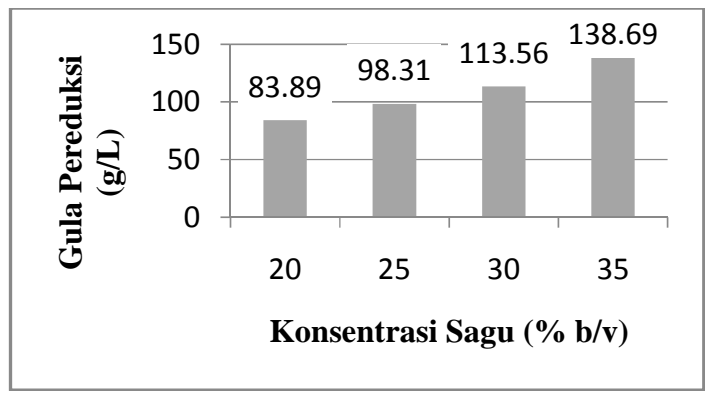

Gambar 1 Hubungan Penggunaan Variasi Konsentrasi Pati Sagu dan Gula Pereduksi (g/L) Maltodekstrin

Gambar 1 menunjukkan bahwa nilai gula pereduksi meningkat secara signifikan setiap peningkatan konsentrasi sagu. Nilai gula pereduksi paling rendah adalah tinggi adalah 83,89 $\mathrm{g} / \mathrm{L}$ pada penggunaan konsentrasi sagu $20 \%$ sedangkan nilai gula pereduksi tertinggi adalah $138.69 \mathrm{~g} / \mathrm{L}$ pada penggunaan konsentrasi sagu 35\%.Hasil analisa lanjut Duncan dengan penggunaan variasi konsentrasi sagu terhadap nilai gula pereduksi maltodekstrin menunjukkan bahwa penggunaan konsentrasi sagu meningkat secara signifikan setiap penambahan konsentrasi sagu.

Peningkatan nilai gula pereduksi yang semakin besar seiring meningkatnya konsentrasi sagu disebabkan oleh meningkatnya jumlah substrat pati yang dapat dihidrolisis. Selama proses likuifikasi oleh enzim komponen pati berupa amilosa dan amilopektin dihidrolisis menjadi gula pereduksi. Konsentrasi substrat yang tinggi memungkinkan terjadinya ikatan kompleks antara substrat pati sagu dan enzim sehingga produk yang dihasilkan berupa gula rantai sedang juga semakin tinggi. Gula-gula rantai sedang yang dihasilkan selama proses likuifikasi adalah maltodekstrin yang merupakan campuran dari glukosa, maltosa, oligosakarida, dan dekstrin. Setiap rantai gula yang terhidrolisis memiliki satu gugus gula pereduksi sehingga semakin banyak pati yang terhidrolisis menjadi gula rantai sedang maka jumlah gula pereduksi juga semakin tinggi. Hal ini sesuai dengan pernyataan (Chen, Wolle, \& Sommer, 2009) yang menyatakan semakin banyak substrat yang ada maka semakin banyak pula ikatan yang terjadi antara enzim dan substrat. Selain itu, hasil penelitian (Ni'maturohmah \& Yunianta., 2004) yang menyatakan bahwa maltodekstrin dapat tersusun dari campuran dari glukosa, maltosa, dekstrin, maltotriosa dan maltotetrosa merupakan salah satu jenis gula pereduksi dari turunan karbohidrat.

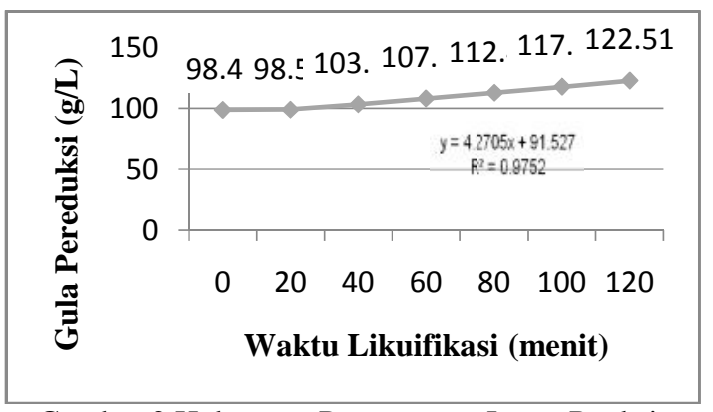

Gambar 2 Hubungan Penggunaan Lama Reaksi Likuifikasi dan Gula Pereduksi (g/L) Maltodekstrin 
Gambar 2 menunjukkan bahwa nilai gula pereduksi meningkat seiring meningkatnya waktu likuifikasi. Hasil analisa lanjutan Duncan terkait lama reaksi likuifikasi terhadap gula pereduksi yang dihasilkan menunjukkan bahwa gula pereduksi meningkat stabil dari menit 0 hingga menit 60. Peningkatan nilai gula pereduksi secara signifikan berturut-turut terjadi dari likuifikasi menit 60 ke menit 80 . Nilai gula pereduksi juga meningkat signifikan dari likuifikasi menit 80 ke likuifikasi menit 100. Nilai gula pereduksi kembali meningkat secara signifikan dari likuifikasi menit 100 ke likuifikasi menit 120.

Peningkatan nilai gula pereduksi seiring bertambahnya waktu likuifikasi diakibatkan oleh bertambahnya waktu interaksi antara substrat berupa pati sagu dengan enzim $\alpha$-amilase dan enzim pullulanase. Interaksi yang terjadi antara substrat sagu dan enzim menyebabkan pemutusan ikatan glikosidik pada pati sagu. Pati sagu akan terhidrolisis menjadi gulagula sederhana seperti glukosa, maltosa, dan oligosakarida. Semakin lama waktu interaksi substrat pati-enzim maka aktivitas enzim untuk memecah pati menjadi gula sederhana semakin tinggi. Setiap rantai gula yang terhidrolisis memiliki satu gugus gula pereduksi sehingga peningkatan jumlah gula sederhana seiring bertambahnya aktivitas pemecahan pati oleh enzim mengakibatkan nilai gula pereduksi juga akan meningkat. Kenaikan gula pereduksi seiring bertambahnya waktu interaksi patienzim juga dinyatakan oleh (Ambriyanto, 2010) yang menyatakan bahwa interaksi antara enzim dengan substrat yang semakin lama menyebabkan semakin banyak glukosa yang terbentuk . (Ni'maturohmah \& Yunianta., 2004) juga menegaskan bahwa maltodekstrin dapat tersusun dari campuran dari glukosa, maltosa, dekstrin, maltotriosa dan maltotetrosa merupakan salah satu jenis gula pereduksi dari turunan karbohidrat.

\subsection{Total Padatan}

Total padatan merupakan jumlah padatan yang terkandung dalam bahan yang mengandung air. Hasil total padatan terlarut akan digunakan untuk menghitung nilai dekstrosa ekuivalen (DE) maltodekstrin yang dihasilkan bersama-sama dengan gula pereduksi.

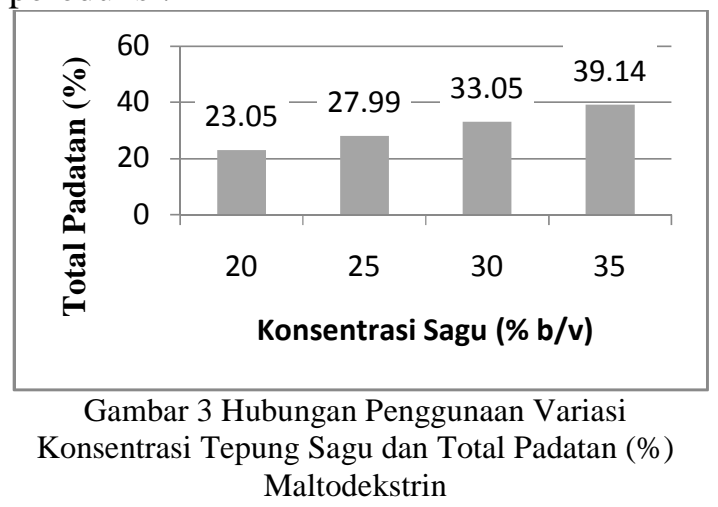

Gambar 3 menunjukkan bahwa nilai total padatan meningkat seiring tingginya konsentrasi sagu. Hasil analisa lanjut Duncan dengan penggunaan variasi konsentrasi sagu terhadap total padatan maltodekstrin menunjukkan bahwa penggunaan konsentrasi sagu 20\% meningkat secara signifikan ke penggunaan konsentrasi sagu 25\%. Peningkatan total padatan juga meningkat dengan signifikan juga terjadi pada penggunaan konsentrasi sagu $25 \%$ ke penggunaan konsentrasi sagu $30 \%$. Begitupun dengan peningkatan total padatan dengan penggunaan konsentrasi sagu $30 \%$ ke penggunaan konsentrasi sagu $35 \%$. mengalami peningkatan yang signifikan.

Peningkatan total padatan yang sangat signifikan seiring meningkatnya konsentrasi sagu diakibatkan oleh meningkatnya jumlah pati dalam suspensi. Pati tersusun dari amilosa dan amilopektin. Selama proses gelatinisasi, ikatan hidrogen granula pati putus oleh pemanasan dan mengkibatkan amilosa dan amilopektin keluar dari granula pati. Amilosa dan amilopektin yang keluar dari granula kemudian tersuspensi dengan air dan meningkatkan total padatan. Gambar 8 menunjukkan peningkatan total padatan seiring meningkatnya konsentrasi pati sagu yang digunakan. Hal ini karena 
kuantitas amilosa dan amilopektin meningkat seiring dengan meningkatnya konsentrasi pati yang digunakan sehingga menyebabkan peningkatan total padatan. Hal ini sejalan dengan penelitian (Kesuma, 2011) yang menyatakan bahwa penambahan bahan pengisi berupa pati pada tepung nanas yang menyebabkan nilai total padatannya menjadi lebih tinggi.

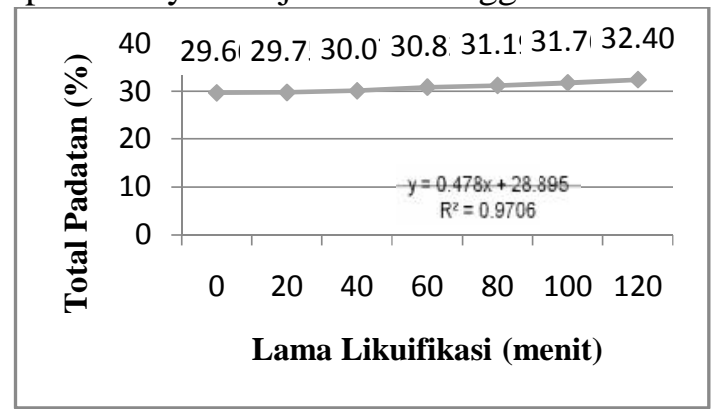

Gambar 4 Hubungan Lama Reaksi Likuifikasi terhadap Total Padatan (\%) Maltodekstrin

Gambar 4 menunjukkan bahwa nilai total padatan meningkat seiring meningkatnya waktu likuifikasi. Hasil analisa lanjut Duncan dengan pengaruh lama reaksi likuifikasi terhadap total padatan maltodekstrin menunjukkan bahwa total padatan meningkat stabil dari waktu likuifikasi menit 0 ke menit 40. Peningkatan secara signifikan terjadi dari menit 40 ke menit 60 kemudian meningkat stabil ke menit 80 . Total padatan kembali meningkat

secara signifikan dari menit 80 ke menit 100 dan kembali meningkat secara signifikan ke menit 120.

Perhitungan nilai total padatan dilakukan dengan menggunakan prinsip kadar air. Kadar air yang tinggi pada maltodekstrin menghasilkan total padatan yang rendah sebaliknya, kadar air maltodektrin yang rendah menghasilkan total padatan yang tinggi. Peningkatan total padatan maltodekstrin pada Gambar 4 diakibatkan oleh tingginya tingkat penguapan air maltodekstrin seiring bertambahnya waktu likuifikasi. Waktu likuifikasi maltodekstrin dengan suhu $80^{\circ} \mathrm{C}$ selama 120 menit mengakibatkan penguapan air yang besar selama proses likuifikasi berlangsung sehingga kadar air dalam maltodekstrin berkurang. Semakin lama proses likuifikasi berlangsung maka semakin tinggi penguapan air yang terjadi. Berkurangnya air akibat penguapan mengakibatkan total padatan menjadi lebih tinggi. Meningkatnya total padatan seiring dengan tingginya penguapan dan kehilangan air juga dikemukakan oleh (Charley \& Weaver, 1998), seiring lamanya waktu ekstraksi zat padatan semakin meningkat, maka jumlah air di dalam produk akan semakin berkurang akibat proses penguapan. Semakin besar air yang menguap karena proses pemanasan, maka zat padatan menjadi tinggi.

\subsection{Dekstrosa Ekuivalen}

Dekstrosa Ekuivalen (DE) adalah besaran yang menyatakan nilai total pereduksi pati atau produk modifikasi pati dalam satuan persen (Lynn, 1997). Hasil analisa sidik ragam nilai dektrosa ekuivalen maltodekstrin yang diperoleh menunjukkan bahwa lama likuifikasi berpengaruh terhadap nilai deksrosa ekuivalen maltodekstrin sehingga dilakukan pengujian lanjutan Duncan lama reaksi likuifikasi terhadap nilai dekstrosa ekuivalen maltodekstrin.

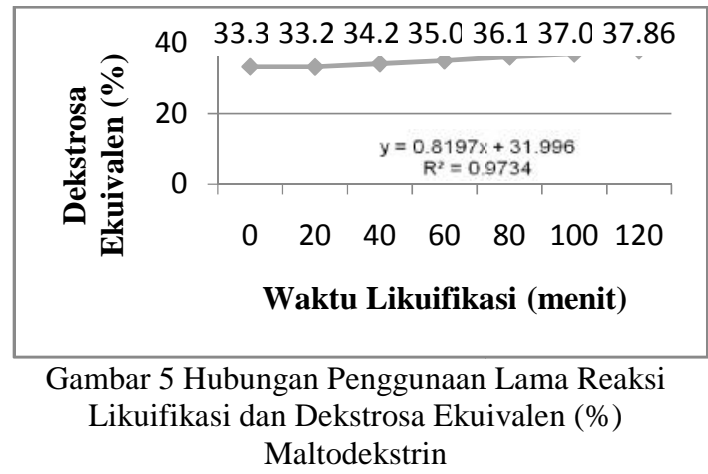

Gambar 5 menunjukkan bahwa nilai dekstrosa ekuivalen meningkat seiring bertambahnya waktu likuifikasi. Hasil analisa lanjut Duncan dengan pengaruh lama reaksi likuifikasi terhadap dekatrosa ekuivalen maltodekstrin menunjukkan bahwa dekstrosa ekuivalen waktu likuifikasi menit 0 meningkat stabil hingga likuifikasi menit 80. Nilai dekstrosa ekuivalen mengalami 
peningkatan yang signifikan berurut-turut dari menit 80 ke menit 100 kemudian meningkat secara signifikan ke menit 120.

Nilai dekstrosa ekuivalen dapat dipengaruhi oleh konsentrasi sagu yang digunakan dan nilai gula pereduksi maltodekstrin. Konsentrasi pati yang digunakan juga mempengaruhi nilai dekstrosa ekuivalen walaupun bukan menjadi satu-satunya penentu nilai dekstrosa ekuivalen. Semakin tinggi konsentrasi yang digunakan maka nilai dekstrosa ekuivalen cenderung menurun, sebaliknya, semakin rendah konsentrasi pati yang digunakan maka nila dekstrosa ekuivalen cenerung meningkat. Keterkaitan ini diakibatkan karena nilai dektrosa ekuivalen ditentukan dengan menggunakan total padatan bersama dengan nilai gula pereduksi. Selain itu, nilai dekstrosa ekuivalen juga mempunyai kolerasi dengan nilai gula pereduksi. Proses likuifikasi yang lama menyebabkan semakin banyak pati terhidrolisis menjadi gula rantai pendek seperti glukosa, maltosa dan maltoteriosa. Setiap rantai gula yang terhidrolisis memiliki satu gula pereduksi sehingga semakin banyak gula rantai pendek yang terbentuk maka gula pereduksi juga semakin tinggi. Hidrolisis dengan waktu lama mengakibatkan meningkat pati terhidrolisis menjadi gula pereduksi dan rantai pati semakin pendek. Hal ini sesuai dengan pernyataan (Ni'maturohmah \& Yunianta., 2004) yang menyatakan bahwa maltodekstrin dapat tersusun dari campuran dari glukosa, maltosa, dekstrin, maltotriosa dan maltotetrosa merupakan salah satu jenis gula pereduksi dari turunan karbohidrat. Keterkaitan antara nilai lama reaksi dan nilai dekstrosa ekuivalen juga dinyatakan oleh (Awwalurrizki \& Putra, 2008) ) yang menyatakan bahwa semakin lama waktu hidrolisa maka sisi aktif enzim lebih lama menempel pada substrat sehingga komponen pati yang akan terpecah rantainya membentuk glukosa semakin banyak.

\subsection{Pati Sisa}

Tujuan pengujian kadar pati sisa adalah untuk menganalisis kuantitas pati sagu yang belum terhidrolisis secara sempurna menjadi maltodekstrin.

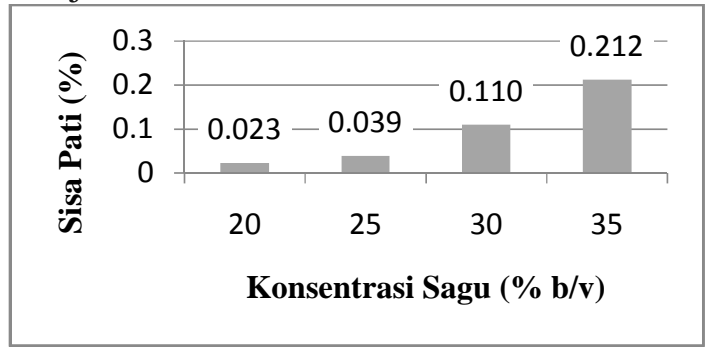

$$
\begin{gathered}
\text { Gambar } 6 \text { Hubungan Penggunaan Variasi } \\
\text { Konsentrasi Tepung Sagu dan Kadar Pati Sisa (\%) } \\
\text { Maltodekstrin }
\end{gathered}
$$

Hasil analisa lanjutan Duncan variasi konsentrasi sagu terhadap pati sisa menunjukkan bahwa peningkatan pati sisa pada konsentrasi sagu $20 \%$ meningkat stabil hingga konsentrasi sagu 25\%.Akan tetapi, nilai pati sisa meningkat secara signifikan dari konsentrasi sagu 25\% ke penggunaan konsentrasi sagu $30 \%$. Begitupun dengan pati sisa dari konsentrasi $30 \%$ ke penggunaan konsentrasi sagu 35\% (Gambar 6).

Kadar pati sisa meningkat seiring dengan meningkatnya konsentrasi sagu menunjukkan bahwa pada suspensi dengan konsentrasi pati tinggi terdapat lebih banyak struktur kristal yang tidak dapat dihidrolisis sehingga nilai pati sisa meningkat seiring bertambahnya konsentrasi pati dalam suspensi. Pati sisa yang rendah diakibatkan karena masih ada pati sagu yang tidak terhidrolisis menjadi maltodekstrin. Pemanasan yang dilakukan dengan suhu tinggi pada tahap gelatinisasi tidak dapat menembus sejumlah daerah kristal pada garnula pati sagu. Daerah kristal pada pati sagu memiliki beberapa jenis diantaranya adalah daerah kristal pati tipe A. Daerah kristal tipe A disusun dari gabungan dari struktur paralel dari dua doubel heliks gugus glukosa yang membentuk susunan heksagonal dengan untaian double heliks tambahan dalam susunan heksagonal tersebut. Oleh karena itu, daerah kristal tipe A memiliki struktur yang paling kompak 
diantara semua jenis daerah kristal pati karena ikatan hidrogen dalam fraksi amilopektin daerah kristal tipe A lebih sulit untuk merenggang dan terlepas oleh suhu tinggi. Hal ini sesuai dengan pernyataan (Zobel, 1988) yang menyatakan bahwa tipe A terdiri dari gabungan dari struktur paralel dari dua doubel heliks yang membentuk susunan heksagonal selain itu, struktur tipe A memiliki untaian double heliks tambahan.

\subsection{Viskositas}

Parameter yang digunakan untuk menentukan produk berbasis pati adalah viskositas dingin yang menujukkan kemampuan pati atau tepung membentuk gel setelah pemasakan. Viskositas diukur pada fase viskositas dingin pada suhu $50^{\circ} \mathrm{C}$.

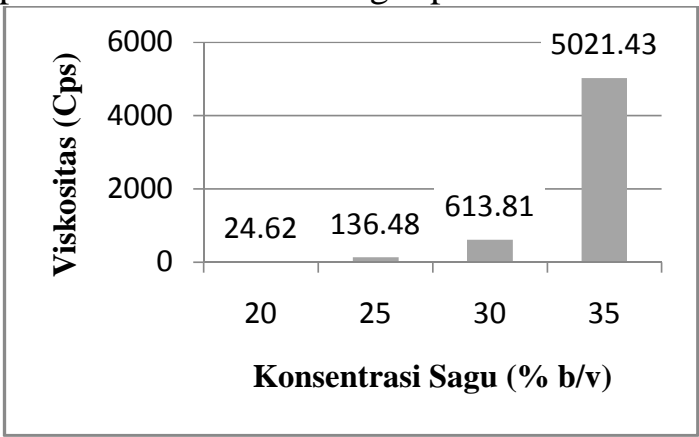

\footnotetext{
Gambar 7 Hubungan Penggunaan Variasi Konsentrasi Tepung Sagu dan Viskositas (Cps) Maltodekstrin
}

Hasil analisa lanjutan Duncan variasi konsentrasi sagu terhadap viskositas menunjukkan bahwa peningkatan pati sisa pada konsentrasi sagu $20 \%$ meningkat stabil hingga konsentrasi sagu $25 \%$ dan meningkat secara signifikan pada penggunaan konsentrasi $30 \%$ kemudian kembali meningkat secara signifikan pada penggunaan konsentrasi 35\% (Gambar 7).

Nilai viskositas yang meningkat seiring bertambahnya konsentrasi sagu yang digunakan diakibatkan karena bertambahnya konsentrasi pati sagu dalam suspensi. Pati sagu terdiri atas amilosa dan amilopektin sehingga semakin tinggi konsentrasi pati sagu dalam suspensi maka semakin tinggi pula amilosa dan amilopektin. Amilopektin berperan dalam pembentukan sifat gel pada pati. Hal ini karena amilopektin memiliki rantai cabang yang cukup besar hingga 5\%. Rantai cabang pada amilopektin memiliki sifat retrogradasi yang rendah sehingga air yang terikat pada gugus hidroksil amilopektin lebih sulit untuk berdifusi keluar. Oleh karena itu, semakin banyak rantai cabang pada amilopektin maka viskositas gel yang terbentuk juga semakin tinggi. Hal ini sesuai dengan pernyataan (Puspasari, 2012). yang menyatakan bahwa Proses pemanasan akan menyebabkan granula pati semakin membengkak karena penyerapan air semakin banyak.

\section{KESIMPULAN}

Variasi konsentrasi sagu terbaik adalah pada konsentrasi $35 \%$ dari segi parameter gula pereduksi, total padatan, dekstrosa ekuivalen dan viskositas dengan masing-masing nilai sebesar $138.69 \mathrm{~g} / \mathrm{L}$, $39.14 \%, \quad 35.37 \%$, dan 5021.43 Cps. Sedangkan lama hidrolisis terbaik dalam pembentukan maltodekstrin adalah pada 120 menit dari segi parameter gula pereduksi, total padatan dekstrosa ekuivalen dan viskositas dengan nilai sebesar 158.25 $\mathrm{g} / \mathrm{L}, 41.28 \%, 38.35 \%$ dan $1701.42 \mathrm{Cps}$.

\section{DAFTAR PUSTAKA}

Ambriyanto. (2010). Isolasi dan Karakterisasi Bakteri Aerob Pendegradasi Selulosa dari Serasah Daun Rumput Gajah (Pennisetum purpureum schaum. Institut Teknologi Sepuluh Nopembe.

Awwalurrizki, \& Putra. (2008). Hidrolisis Sukrosa Dengan Enzim Invertase Untuk Produksi Etanol Menggunakan Zymomonas Mobilis. Prosiding. Institut Teknologi Sepuluh Nopember.

Charley, \& Weaver. (1998). Foods (A Scientific Approach). Prentice hall Inc New Jersey: Prentice hall Inc.

Chen, C., Wolle, D., \& Sommer, D. (2009). The Sensory Evaluation of Dairy Products. The Sensory Evaluation of Dairy Products. https://doi.org/10.1007/978-0-387- 
$77408-4$

Kesuma. (2011). Pengaruh dan Jenis

Konsentrasi Sagu terhadap

Karakteristik Tepung Nanas (Ananas Comocus (L) Merr) dan Pengaruh CMC Terhadap Karakteristik Velva Berbahan Dasar Tepung Nanas. Institut Teknologi Bandung.

Laga, A. (2001). Produksi Siklodestrin Menggunakan Substrat Tapioka Terlikuifikasi dengan Aseptor Minimal. IPB, Bogor.

Lynn. (1997). Making the Most of Maltodextrins. Retrieved from www.foodproductdesign.com.

Miller. (1959). Use of Dinitrosalicylic Acid Reagent for Determination of Reducing Sugar. Analytical Chemistry. Ni'maturohmah, \& Yunianta. (2004). Hidrolisis Pati Sagu (Metroxylon sagu Rottb.) oleh Enzim $\beta$-amilase untuk Pembuatan Dekstrin. Agroindustri, Hidrolisis Pati Sagu Untuk Pembuatan Deskstrin. Jurnal Pangan Dan, 3(1), 292-302.

Perkebunan, B. P. B. (2008). Sagu Sebagai Sumber Energi Alternatif.

Puspasari. (2012). Pemanfaatan Tepung Kimpul (Xanthosoma sagittifolium) Terfermentasi sebagai Bahan Baku pembuatan Beras Tiruan (Kajian Proporsi Tepung Kimpul Terfermentasi: Tepung Mocaf). Malang.

Sadegh, Shahidi, \& Mortazav. (2008). Evaluation of Different Parameters Effect on Maltodextrin Production by "-amylase Termamyl 2-x. World Applied Sciences Journa, 1(13), 34-39.

Shi Y.C., Eden, J.L., Kasica, J.J., and J. (2000). Patent 6,054,302. u.s.

Vasanthan, T., \& Bhatty, R. S. (1996). Physicochemical properties of smalland large-granule starches of waxy, regular, and high-amylose barleys. Cereal Chemistry.

Zobel, H. F. (1988). Starch Crystal Transformations and Their Industrial Importance. Starch - Stärke. https://doi.org/10.1002/star.198804001 